\title{
РАЗРАБОТКА АГЕНТОВ КОМБИНИРОВАННОГО ДЕЙСТВИЯ НА ОСНОВЕ ПРОИЗВОДНЫХ ПРИРОДНЫХ ХЛОРИНОВ
}

\author{
С.И. Тихонов, В.В. Голодная, Е.С. Олейник, Н.Ю. Демчук, \\ М.А. Евдокимова, А.Д. Фадеева, М.А. Грин
}

МИРЭА - Российский технологический университет, Институт тонких химических технологий им. М.В.Ломоносова, 119571, Россия, Москва, пр. Вернадского 86.

DOI: 10.19163/MedChemRussia2021-2021-334_E-mail: deviantprince13th@gmail.com

На сегодняшний день актуальной задачей медицинской химии является создание препаратов комбинированного действия. Одним из перспективных направлений комбинированной терапии является сочетание химиотерапии и ФДТ. Платформой для таких препаратов могут стать производные природных хлоринов, которые являются высоко эффективными фотосенсибилизаторами (ФС). Присоединение к этим молекулам комплексов металлов позволит получить агенты с таргетной доставкой и высокой эффективностью в отношении опухолей различного генеза. Ранее в нашей научной группе уже были получены подобные агенты и доказано их комбинированное действие [1].

В данной работе были использованы С-донорные комплексы золота (I) и карбоксилатные комплексы олова (IV). Были получены конъюгаты на основе аминокислот и биогенных аминов, изучены их спектральные свойства, а также был проведен докинг в отношении характерных мишеней. Результаты расчетов докинга показали, что предпочтительными мишенями для полученных комплексов являются ДНК, тиоредоксин и теоредоксин редуктаза. Результаты докинга в отношении ДНК были подтверждены тестом связывания.

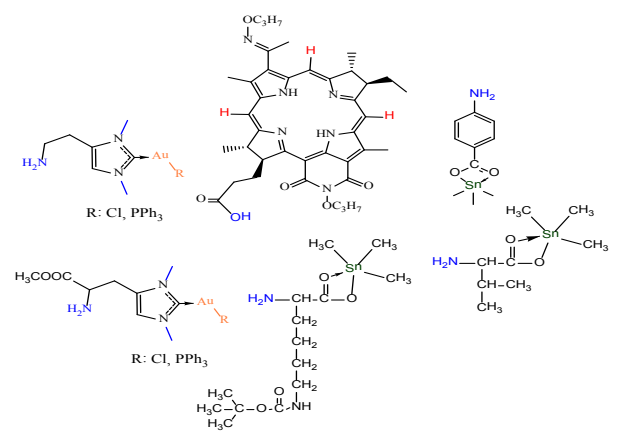

Работа выполнена при поддержке гранта РФФИ № 19-03-00302.

\section{Литература}

1. Mikhail A. Grin, et. al. New Derivatives of Bacteriopurpurin With Thiolated Au (I) Complexes:

Dual Dark- and Light Activated Antitumor Potency // Anticancer Drug Research 2020, 20, 1 